\title{
PERILAKU CHAOS ALIRAN FLUIDA BERDENYUT DALAM SALURAN BERPENAMPANG SEGIEMPAT
}

\author{
Prayitno Ciptoadi ${ }^{1 *}$, M. F. Noya ${ }^{2}$ dan, G. S. Norimarna ${ }^{3}$ \\ 1Jurusan Teknik Mesin Fakultas Teknik Universitas Pattimura, Ambon, 97234 \\ *Email: pciptoadi69@gmail.com \\ 2Jurusan Teknik Mesin Fakultas Teknik Universitas Pattimura, Ambon, 97234 \\ Email: mfnoya@fatek.unpatti.ac.id \\ 3Jurusan Teknik Mesin Fakultas Teknik Universitas Pattimura, Ambon, 97234 \\ Email: gsnorimarna@fatek.unpatti.ac.id
}

\begin{abstract}
Abstrak. Aliran fluida berdenyut di dalam saluran beralur melintang akan menjadi aliran chaos meskipun pada bilangan Reynold yang rendah. Bilangan Reynold dimana aliran mengalami chaos dipengaruhi oleh jarak antar alur. Penelitian ini bertujuan mengetahui pengaruh jarak alur terhadap perilaku chaos. Penelitian dilakukan pada sebuah saluran tertutup berpenampang segiempat yang diberi alur setengah lingkaran pada dinding bagian bawah. Pengukuran frekuensi osilasi aliran dilakukan dengan menggunakan sensor tahanan yaitu jembatan Wheatstone dimana sensor tahanan dipasang dalam manometer pipa U. Pengukuran dilakukan terhadap aliran pada beberapa bilangan Reynold. Hasil penelitian menunjukan aliran fluida periodik dalam saluran yang beralur melintang telah mengalami chaos pada bilangan Reynold Re 950 untuk saluran tanpa alur dan bilangan Reynold Re 700 untuk saluran beralur. Terjadinya chaos ini diakibatkan oleh timbulnya vortex pada setiap perlakuan.
\end{abstract}

Kata kunci: Aliran berdenyut, saluran beralur, vortex, chaos.

\begin{abstract}
The pulsatile fluid flow in a transverse grooved channel would becomes chaotic flows in low Reynold numbers. The Reynold number where flows become chaos depends on grooves distances. The objective of this research is to analyze the effect of grooves distances toward the behaviour of chaos. This research was done by implementing a closed square cross section channel, where the bottom surface of the channel was semicircle grooved. The frequency of flow oscillation measurement was done by setting up a resistance sensor that is Wheatstone bridge where the resistance sensor was located in a $U$ manometer. Measurement was done at severals Reynold number. From the research result it is seen that the periodic fluid flows in the transverse grooved channel had became chaos at Reynold number Re 950 in channel without grooved and at Reynold number Re 700 in grooved channel. Chaos took placed since vortex appeared at every treatment.
\end{abstract}

Keywords: Pulsatile flow, grooved channel, vortex, chaos.

\section{PENDAHULUAN}

Chaos (chaotic) adalah istilah yang diberikan kepada sistem-sistem fisis dan matematis deterministik (deterministic) yang bergerak dimana jejak sistem-sistem tersebut sensitif terhadap kondisi awal (sensitive dependence on initial condition). Harus dibedakan istilah gerakan acak (random motion) dan gerakan chaos (chaotic motian). Istilah gerakan acak diperuntukan bagi masalah dimana sama sekali tidak diketahui gayagaya input atau hanya diketahui beberapa parameter secara statistik. Sedangkan istilah gerakan chaos diperuntukan bagi masalah deterministik dimana tidak ada input atau parameter yang acak atau tak terprediksi [1]. Dengan kata lain, sistem deterministik adalah 
sistem dimana persamaan atur (governing equation) dan kondisi awal sistem tersebut diketahui. Meskipun banyak gerak sederhana yang dapat diprediksi kondisinya yang akan datang, tetapi gerak yang rumit seperti gerak yang tidak periodik (non-periodic motion) tidak dapat diprediksi kondisinya yang akan datang. Perbedaaan hasil prediksi ini disebabkan oleh ketidaklinearan persamaan atur (non-linearity of the governing equations). Hal ini menunjukan bahwa ketidaklinearan memunculkan gerak rumit yang tidak dapat diprediksi, yaitu: gerakan chaos. Dengan kata lain, kita dapat memprediksi gerak rumit, yang selama ini dianggap tidak dapat diprediksi, jika kita memahami ketidaklinearan. Pemahaman tentang dinamika non-linear adalah kunci untuk melangkah ke bidang sains dan teknologi abad ke-21 [2].

Chaos ditandai dengan munculnya atraktor aneh (strange attractor). Terdapat tiga jenis gerak dinamik klasik yaitu: 1. Kesetimbangan (equilibirium), 2. Gerak Periodik atau Siklus Terbatas (Periodic Motion or Limit Cycle), 3. Gerak Kuasiperiodik (Quasiperiodik Motion). Ketiga jenis gerak tersebut dinamakan Atraktor (attractor) karena jika redaman pada suatu sistem transient ditiadakan, sistem akan "ditarik" ke salah satu jenis gerak diatas. Terdapat satu jenis gerak lain dalam dinamika non-linear yang tidak termasuk ke salah satu dari ke tiga jenis atraktor klasik di atas. Jenis gerak baru ini adalah gerak chaos yang bermakna tidak dapat diprediksi jika terjadi suatu ketidakpastian kecil pada kondisi awal, dan sering juga dihubungkan dengan keadaan gerak yang dinamakan atraktor aneh (strange attractor). Aspek lain dari chaos yaitu terjadinya bifurkasi (bifurcation) yaitu berpindahnya titik stabilitas dan berubahnya jumlah titik kesetimbangan suatu sistem dinamik jika parameter sistem berubah. Diagram bifurkasi dari suatu sistem dinamik menyajikan keadaan transisi antara jenis gerak berbeda yang terjadi jika parameter sistem berubah. Sumbu horizontal diagram bifurkasi adalah parameter sistem sedangkan sumbu vertikal adalah atraktor [3].

Pada aliran laminar di dalam saluran beralur melintang terdapat dua daerah aliran: (i) aliran utama dalam saluran dan (ii) aliran vortex resirkulasi dalam alur. Dua daerah tersebut dipisahkan oleh lapisan geser bebas (free shear layer). Dalam kondisi stedi, tidak ada pertukaran fluida antara kedua daerah ini. Salah satu kemungkinan untuk meningkatkan laju transport dalam saluran beralur adalah memperbaiki pencampuran lateral (lateral mixing) dengan mengganggu lapisan geser pemisah antara aliran utama dan aliran resirkulasi dalam alur. Gerakan aliran utama dari hulu ke hilir mengalami defleksi ke dalam alur pada Re 50 sementara aliran vortex di dalam alur bergerak ke hilir seiring meningkatnya Re. Osilasi aliran terjadi akibat aliran stedi menjadi tidak stabil karena mengalami bifurkasi pada bilangan Reynold kritis tertentu. Ketidakstabilan ini muncul karena dipicu oleh munculnya Tollmien-Schlichting wave. Aliran yang berosilasi menginduksi tegangan Reynold (Reynold stress) dan mampu meningkatkan difusi momentum yaitu mengangkut energi dari aliran utama ke aliran osilasi dan mempertahankannya. Akibatnya rugi tekanan (pressure drop) dari aliran utama meningkat. Ketidakstabilan KelvinHelmholtz terbentuk pada tepi alur disebabkan oleh formasi pelengkungan lintasan profil kecepatan, menekan gelombang TollmienSchlichting di bagian luar alur dan memproyeksikan energi padanya. Akibat dari interaksi kompleks, menghasilkan gelombang berjalan dua dimensi (two-dimensional traveling waves) pada bilangan Re cukup rendah [4].

Aliran laminar dalam saluran beralur yang bertujuan untuk meningkatkan laju transport banyak dijumpai. Dalam bidang teknik seperti alat penukar kalor (compact heat exchanger), sistem pendingin mikroelektronik dan juga dalam bidang kedokteran serta biokimia [5]. Banyak penelitian telah dilakukan untuk mengetahui perilaku aliran fluida dalam saluran beralur melintang. Penelitian-penelitian tersebut dilakukan pada berbagai kondisi aliran baik kontinyu maupun berdenyut dan berbagai bentuk alur seperti segiempat, segitiga atau setengah lingkaran namun jarak alur tetap. Oleh karena itu penelitian ini memberikan data perilaku chaos aliran fluida berdenyut dalam saluran beralur melintang dengan jarak alur yang berubah-ubah.

\section{BAHAN DAN METODE}

\subsection{Teori}

Chaos terjadi jika terdapat ketidaklinearan [6]. Fungsi kuadrat $y=a x^{2}+b x+c$, jika dibuat $c=$ 0 dan $a=-b$ akan menjadi $y=-b x^{2}+b x=$ $b x(1-x)$ [7]. Persamaan di atas dikenal sebagai Persamaan Logistik yang jika diiterasikan dengan bentuk [8].

$$
x_{t+1}=k x_{t}\left(1-x_{t}\right) \text {, dengan } k=b
$$

akan menunjukan perilaku chaos. Hasil iterasi untuk $\mathrm{k}=0,95$ konvergen $\mathrm{ke} 0, \mathrm{k}=1,4$ konvergen ke $0,286, \mathrm{k}=2,8$ konvergen ke 0,643 seperti terlihat pada Gambar 1, 2, dan 3. Selanjutnya hasil iterasi untuk $\mathrm{k}=3,4$ telah terjadi bifurkasi dengan terbentuk dua titik kesetimbangan yang 
berbeda yaitu: 0,452 dan 0,842 seperti terlihat pada Gambar 4.

Selanjutnya hasil iterasi untuk $\mathrm{k}=3,75$ terjadi bifurkasi dengan terbentuk banyak sekali titik kesetimbangan yang mengindikasikan sistem sepenuhnya dalam keadaan chaos seperti pada gambar 5. Fenomena ini membuktikan bahwa sistem dinamik yang non-linear sensitif terhadap kondisi awal.

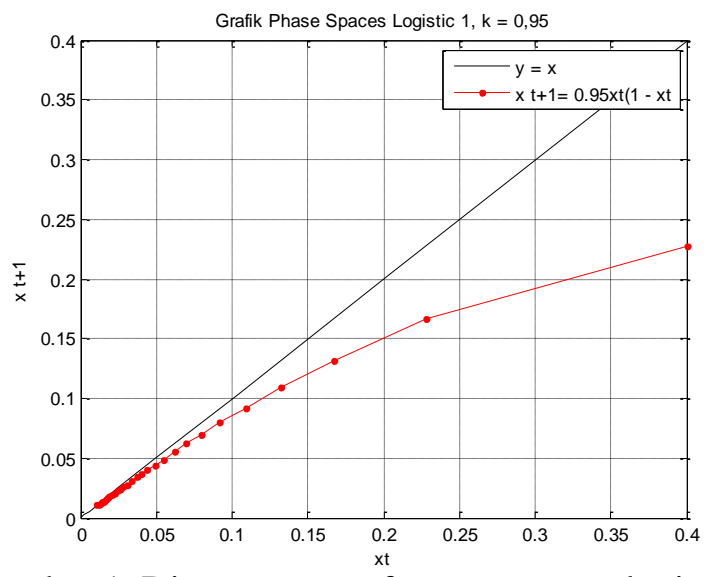

Gambar 1. Diagram ruang fasa persamaan logistik $\mathrm{k}=0,95$

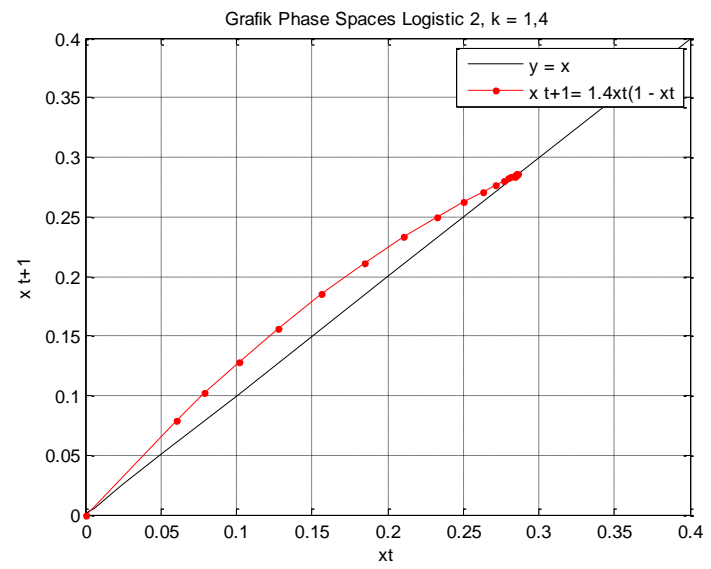

Gambar 2. Diagram ruang fasa persamaan logistik $\mathrm{k}=1,4$

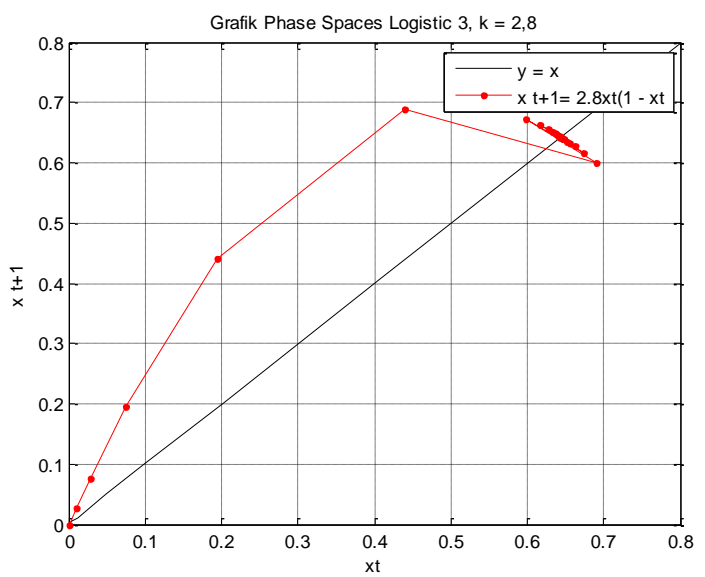

Gambar 3. Diagram ruang fasa persamaan logistik $\mathrm{k}=2,8$

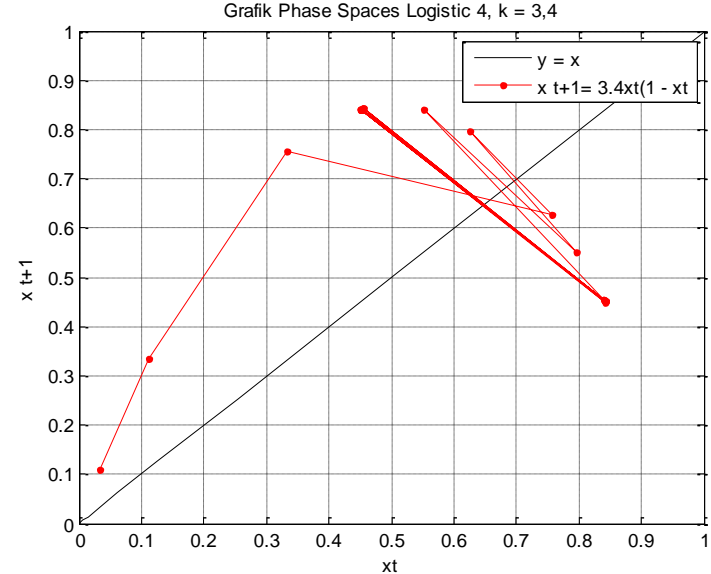

Gambar 4. Diagram ruang fasa persamaan logistik $\mathrm{k}=3,4$

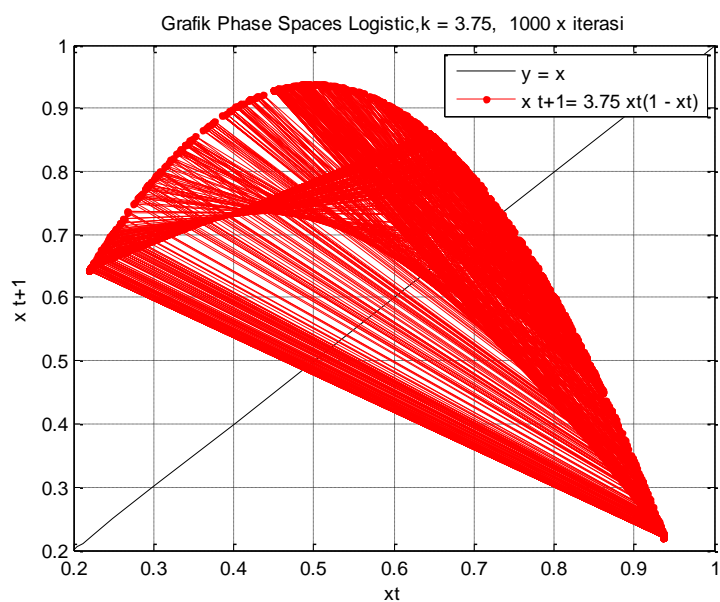

Gambar 5. Diagram ruang fasa persamaan logistik $\mathrm{k}=3,75$

Diagram bifurkasi persamaan logistik untuk k $=0,95$ sampai dengan 3,6 diperlihatkan pada gambar 6, sedangkan diagram bifurkasi persamaan logistik sepenuhnya chaos diperlihatkan pada gambar 7 .

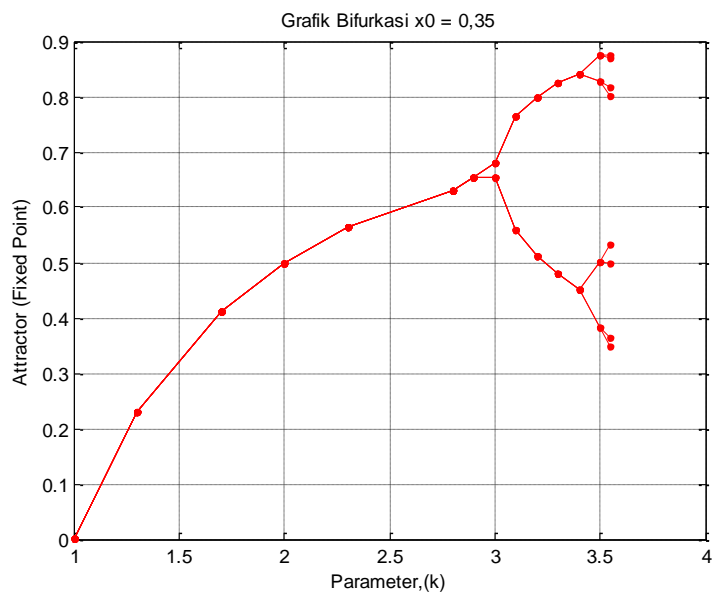

Gambar 6. Diagram bifurkasi persamaan logistik dengan $\mathrm{k}=0,95-3,6$ 


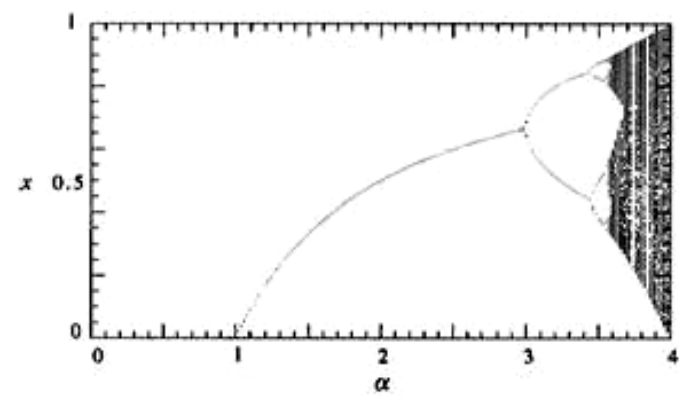

Gambar 7. Grafik bifurkasi persamaan logistik [9]

Karakteristik osilasi aliran ditentukan oleh bilangan Strouhal Str dengan persamaan [10].

$$
S t r=\frac{f h}{U}
$$

dengan $f=$ frekuensi osilasi aliran, $\mathrm{Hz}$

$\mathrm{h}=$ tinggi saluran, $\mathrm{m}$

$U=$ kecepatan fluida, m.det $^{-1}$

Gerakan fluida diatur oleh persamaan Navier Stokes yang ditulis dalam notasi vektor sebagai berikut [10].

$$
\rho\left[\frac{\partial U}{\partial t}+(U \bullet \nabla) U\right]=-\nabla p+\rho g+\mu \nabla^{2} U
$$

dengan:

$$
\begin{aligned}
& \mu=\text { viskositas dinamik, N.det. } \mathrm{m}^{-2} \\
& \mathrm{p}=\text { tekanan fluida, } \mathrm{N} \cdot \mathrm{m}^{-2} \\
& \rho=\text { densitas fluida, } \mathrm{kg} \cdot \mathrm{m}^{-3} \\
& \mathrm{~g}=\text { percepatan gravitasi, m.det }{ }^{-2} \\
& t=\text { waktu, det }
\end{aligned}
$$

Didefenisikan vorticity vector $\Omega$, suatu ukuran dari efek rotasi lokal elemen fluida [10].

$$
\Omega=\operatorname{curl} U=2 \times \omega
$$

Jika diambil curl dari persamaam (3) diperoleh persamaan transport vorticity [11]

$$
\frac{\partial \Omega}{\partial t}+(U \bullet \nabla) \Omega=(\Omega \bullet \nabla) U+v \nabla^{2} \Omega
$$

\subsection{Metode Penelitian}

Penelitian dilakukan dengan menggunakan peralatan seperti pada gambar 8 . Saluran dibuat dari bahan tembus pandang (mika) berpenampang segiempat. Ukuran saluran adalah panjang $1=450$ $\mathrm{mm}$, lebar $\mathrm{W}=120 \mathrm{~mm}$, tinggi $\mathrm{h}=14 \mathrm{~mm}$. Bagian atas saluran dibuat rata sedangkan bagian bawah diberi alur (groove). Alur dibuat berbentuk setengah lingkaran dengan ukuran jari-jari $r=$ $11,5 \mathrm{~mm}$.

Jumlah alur yang digunakan dua buah dengan jarak antar alur $\mathrm{L}$ dibuat periodik terhadap keliling alur $\mathrm{K}$ yaitu $1 / 2 \mathrm{~K}(\mathrm{G} 1), 3 / 4 \mathrm{~K}(\mathrm{G} 2)$ dan $\mathrm{K}$ (G3) dengan $\mathrm{K}=72,22 \mathrm{~mm}$.

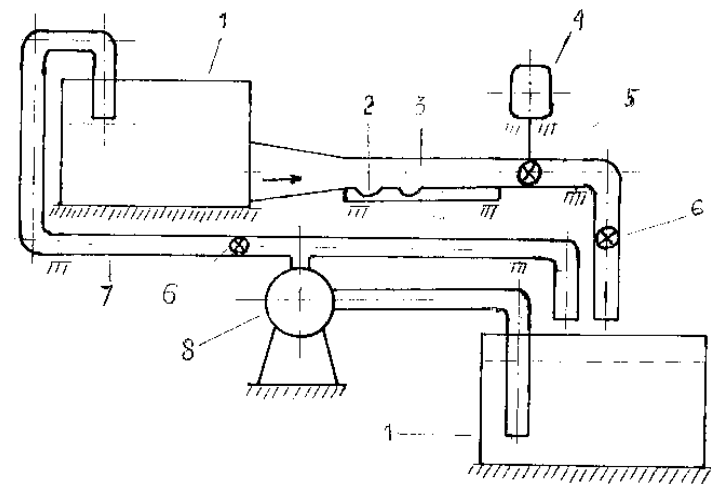

Gambar 8. Instalasi penelitian

Kerangan:

1. Tandon air

2. Alur setengah lingkaran

3. Saluran

4. Motor listrik

5. Katup denyut

6. Katup pengatur aliran

7. Pipa-pipa

8. Pompa

Agar aliran dapat berdenyut, sebuah katup denyut yang digerakan oleh motor listrik dengan kecepatan putar 66 rpm ditempatkan pada bagian hilir saluran. Sebagai pembanding digunakan juga saluran tanpa alur (G0). Fluida kerja yang digunakan adalah air, kondisi aliran laminar dua dimensi. Variabel penelitian meliputi variabel bebas yaitu: Bilangan Reynold Re dan Jarak antar alur L sedangkan variabel terikat yaitu: frekuensi osilasi aliran.

\section{Teknik Pengambilan data}

\section{Pengukuran Debit Aliran}

Pengukuran debit aliran Q, berdasarkan volume air yang mengalir per satuan waktu. Volume air yang mengalir diatur melalui pembukaan katup yang ditempatkan sebelum dan sesudah saluran beralur. Data debit aliran digunakan untuk menentukan kecepatan aliran fluida dan bilangan Reynold. Kecepatan aliran fluida = debit aliran dibagi luas penampang saluran $(\mathrm{U}=\mathrm{Q} / \mathrm{A})$ sedangkan bilangan Reynold $\mathrm{Re}$ dihitung dengan menggunakan persamaan [12].

$$
\operatorname{Re}=\frac{U h}{v}
$$

dengan,

$U=$ laju aliran, m.det $^{-1}$

$h=$ tinggi saluran, $\mathrm{m}$

$v=$ viskositas kinematik $\left(1,007 \times 10^{-6}, \mathrm{~m}^{2} \operatorname{det}^{-1}\right)$

Hasil perhitungan kecepatan aliran dan $\mathrm{Re}$ dapat dilihat pada Tabel 1. 
Tabel 1. Hasil perhitungan kecepatan aliran dan bilangan Reynold

\begin{tabular}{cccc}
\hline No & Re & Q, m ${ }^{3}$ det $^{-1}$ & ${\mathrm{U}, \mathrm{mdet}^{-1}}^{-1}$ \\
\hline 1 & 200 & $2,42 \times 10^{-5}$ & 0,0144 \\
2 & 450 & $5,44 \times 10^{-5}$ & 0,032 \\
3 & 700 & $8,46 \times 10^{-5}$ & 0,050 \\
4 & 950 & $1,15 \times 10^{-4}$ & 0,068 \\
5 & 1200 & $1,45 \times 10^{-4}$ & 0,086 \\
\hline
\end{tabular}

Sumber: Hasil pengukuran (data diolah)

\section{Pengambilan Data Fluktuasi Kecepatan Aliran}

Pengambilan data seperti terlihat pada gambar

9. Data diambil menggunakan sensor tegangan (salah satu tahanan jembatan Wheatstone) yang ditempatkan di dalam manometer yang berisi air.

Manometer dihubungkan dengan saluran sedangkan sensor dihubungkan dengan ADC. Data ini ditampilkan pada monitor komputer dalam bentuk grafik dan teks kemudian disimpan dalam bentuk teks. Untuk menjamin keakuratan, jumlah data yang diambil adalah 400 data per detik dan dilakukan 5 kali pengulangan untuk tiap perlakuan. Pengambilan data ini diulangi untuk beberapa nilai variabel bebas.

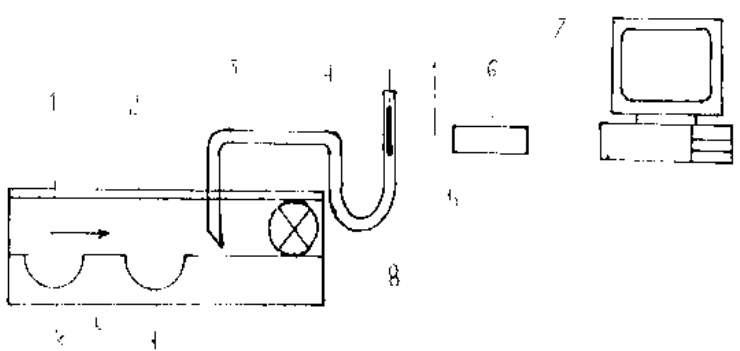

Gambar 9. Pengukuran fluktuasi kecepatan aliran fluida

Keterangan:

1. Saluran

2. Alur setengah lingkaran

3. Pipa plastik

4. Manometer

5. Sensor tegangan

6. ADC

7. PPI card dan komputer

8. Katup denyut

L: Jarak antar alur

\section{HASIL DAN PEMBAHASAN}

Data fluktuasi kecepatan diolah dengan menggunakan program FFT untuk memperoleh frekuensi-frekuensi yang dominan dari tiap-tiap perlakuan. Selanjutnya dari data-data tersebut dihitung bilangan Strouhal Str.

\section{Kekuatan Vortex}

Kekuatan vortex digambarkan dengan bilangan Strouhal, Str dan Energi Kinetik yang dikandung oleh vortex. Pada aliran fluida laminar dalam saluran beralur akan terbentuk shear layer antara aliran utama dalam saluran dan aliran resirkulasi dalam alur. Untuk aliran yang berdenyut, pada fase akselerasi (katup denyut mulai membuka) shear layer mulai mengalami separasi. Sebuah vortex utama terbentuk dalam alur pada tepi atas sisi hulu. Pada saat laju aliran utama maksimum (katup denyut terbuka penuh) vortex utama memenuhi seluruh bagian alur. Ketika fase deselerasi (katup denyut mulai tertutup) vortex utama berkembang hingga keluar dari tepi alur. Disamping itu terbentuk vortex tambahan pada saluran rata dekat dinding bagian atas dengan tanda yang berlawanan dengan vortex utama. Kedua vortex yang berpasangan (vortices) tersebut memenuhi keseluruhan saluran pada saat laju aliran utama minimum (katup denyut tertutup). Setelah itu vortex tambahan menghilang. Proses ini berlangsung terus mengikuti osilasi aliran utama [4].

Dari fenomena di atas dapat dilihat bahwa terjadi penggabungan vortex (merging) ketika laju aliran utama minimum. Proses ini didominasi oleh efek tak stedi $(\partial \Omega / \mathrm{jt})$ dan efek kekentalan $\left(v \mathrm{~V}^{2} \Omega\right)$ dari persamaan (4) sedangkan efek inersia non linear $(\mathrm{U} \cdot \mathrm{V}) \Omega$ berkurang. Pertumbuhan vortex utama di dalam alur selama fase deselerasi menimbulkan semprotan (ejection) fluida di dalam alur dan menghasilkan pertukaran partikelpartikel fluida antara alur dan saluran melintasi shear layer [12]. Interaksi antara vortex utama di dalam alur dan vortex tambahan di dalam saluran juga meningkatkan pencampuran (mixing) fluida yang didominasi oleh efek vortex-stretching $(\Omega \cdot \mathrm{V}) \mathrm{U}$ dari persamaan (4) [13]. Pertukaran partikel-pertikel fluida antara alur dan saluran dihubungkan dengan kekuatan vortex utama dan transport momentum osilasi melintasi shear layer tergantung pada bilangan Re dan bilangan Str. Hubungan antara kekuatan vortex dan bilangan Re 200 dapat dilihat pada gambar 10.

Dari grafik pada gambar 10 terlihat bahwa kekuatan vortex meningkat seiring meningkatnya bilangan Str. Kekuatan vortex mencapai nilai maksimum pada bilangan Str tertentu disebabkan pada nilai bilangan Str tersebut telah terjadi self sustained oscillatory flow. Kondisi ini dikarenakan oleh kecepatan aliran osilasi di dalam alur telah mencapai kecepatan aliran utama di dalam saluran dimana terjadi peningkatan amplitudo vortex utama dan munculnya vortex tambahan. Dari grafik juga dapat dilihat bahwa 
nilai bilangan Str pada mana kekuatan vortex maksimum untuk $\mathrm{G} 1<\mathrm{G} 2<\mathrm{G} 3$. Hal ini mengindikasikan bahwa interaksi antara vortexvortex utama dalam dua alur dipengaruhi oleh jarak antar alur. Interaksi akan lebih kuat dan lebih cepat mencapai nilai maksimum pada jarak antar alur paling pendek. Untuk saluran tanpa alur kekuatan vortex hanya tergantung pada osilasi aliran utama dan nilainya kecil dibandingkan dengan nilai kekuatan vortex pada saluran beralur.

Grafik bilangan Str vs kekuatan vortex diverifikasi dengan penelitian [12] pada bilangan $\mathrm{Re} 200$. Kekuatan vortex maksimum dari Nishimura et. al, (2001) lebih tinggi karena faktor geometri alur. Pada penelitian mereka digunakan alur berbentuk segiempat dengan panjang alur dua kali kedalamannya.

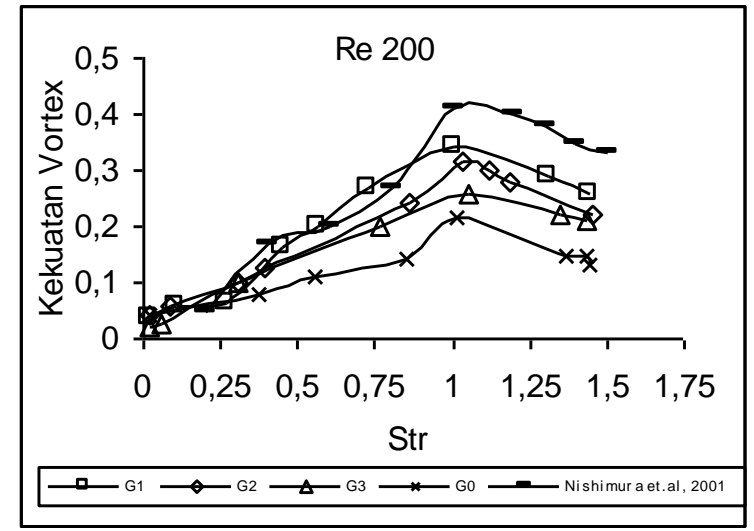

Gambar 10. Grafik kekuatan vortex vs Str

\section{Chaos Pada Aliran Fluida}

Tumbuh dan bergabungnya vortex memicu ketidakstabilan aliran fluida yang menyebabkan chaos. Pada aliran fluida dengan bilangan Rendah yang idealnya aliran dalam kondisi laminar telah muncul aktraktor aneh yang mengindikasikan aliran fluida mengalami chaos. Hal ini membuktikan bahwa aliran fluida laminar yang teratur berpotensi menjadi chaos apabila kondisi awalnya terganggu. Aliran chaos ini berperan penting dalam proses peningkatan perpindahan panas [6].

Atraktor aneh aliran fluida dalam saluran pada perlakuan dengan jarak alur berubah-ubah dapat dilihat pada diagram ruang fasa (phase space diagram) seperti Gambar 11 sampai 14.

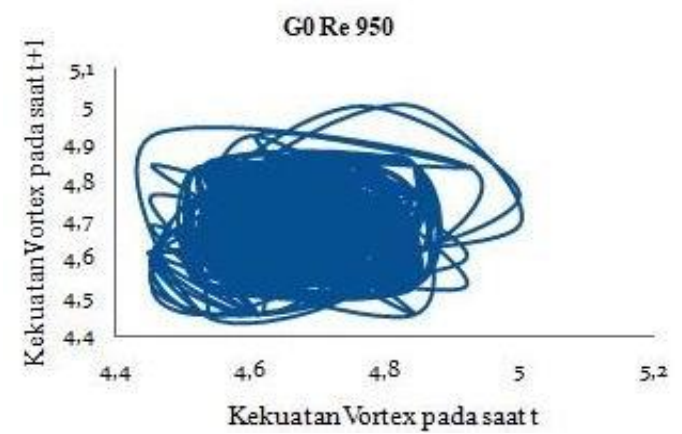

Gambar 11. Diagram ruang fasa aliran fluida pada saluran tanpa alur

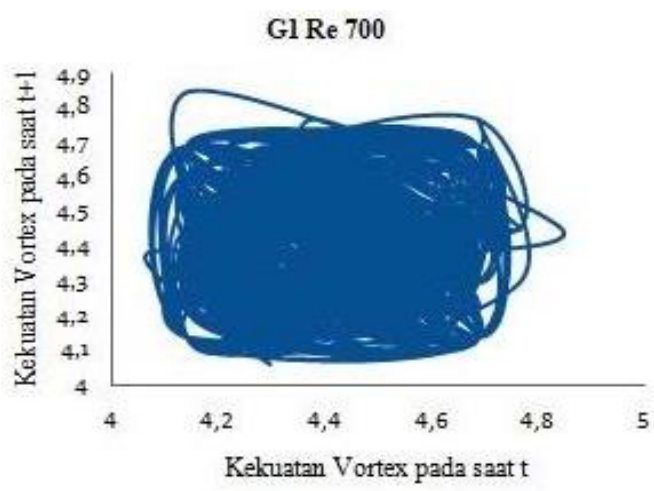

Gambar 12. Diagram ruang fasa aliran fluida pada saluran beralur dengan jarak antar alur $1 / 2 \mathrm{~K}$

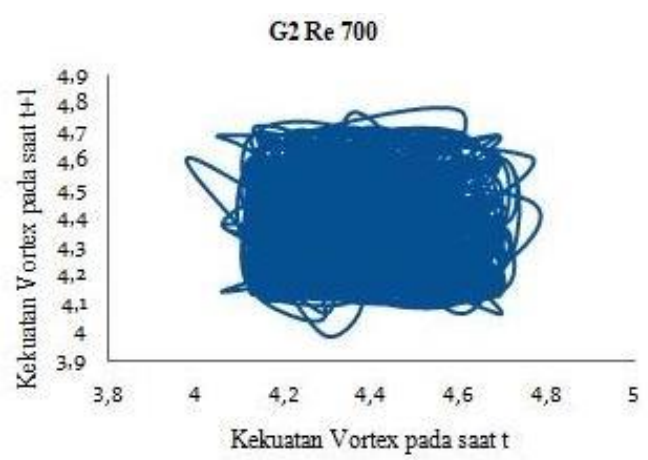

Gambar 13. Diagram ruang fasa aliran fluida pada saluran beralur dengan jarak antar alur $3 / 4 \mathrm{~K}$ 


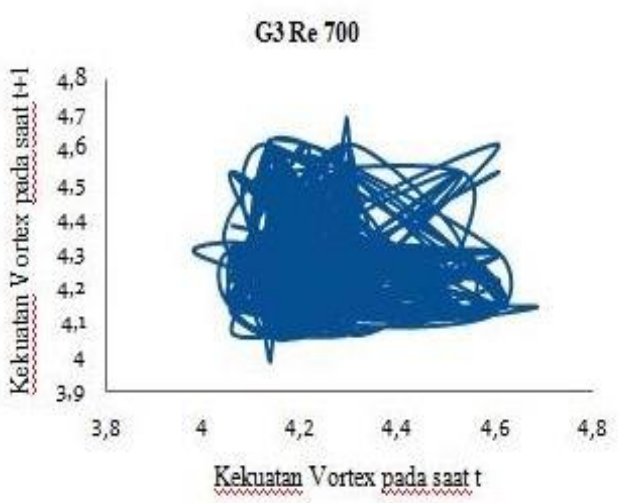

Gambar 14. Diagram ruang fasa aliran fluida pada saluran beralur dengan jarak antar alur K

Diagram bifurkasi aliran fluida tiap perlakuan pada Re tertentu diperlihatkan pada Gambar 15, sampai 18.

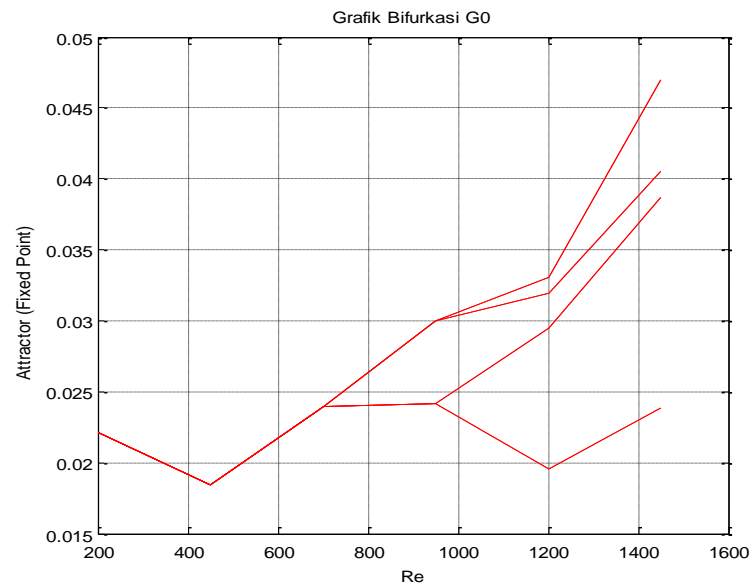

Gambar 15. Diagram bifurkasi aliran fluida pada saluran tanpa alur

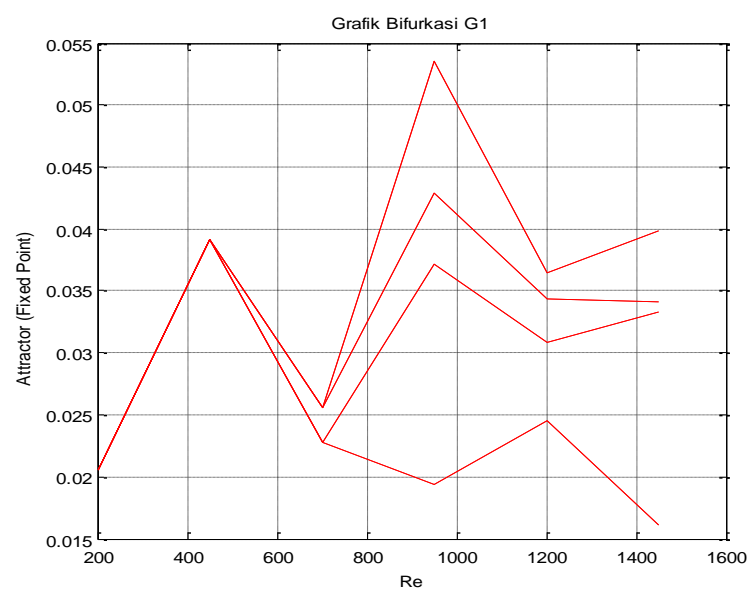

Gambar 16. Diagram bifurkasi aliran fluida pada saluran beralur dengan jarak antar alur $1 / 2 \mathrm{~K}$

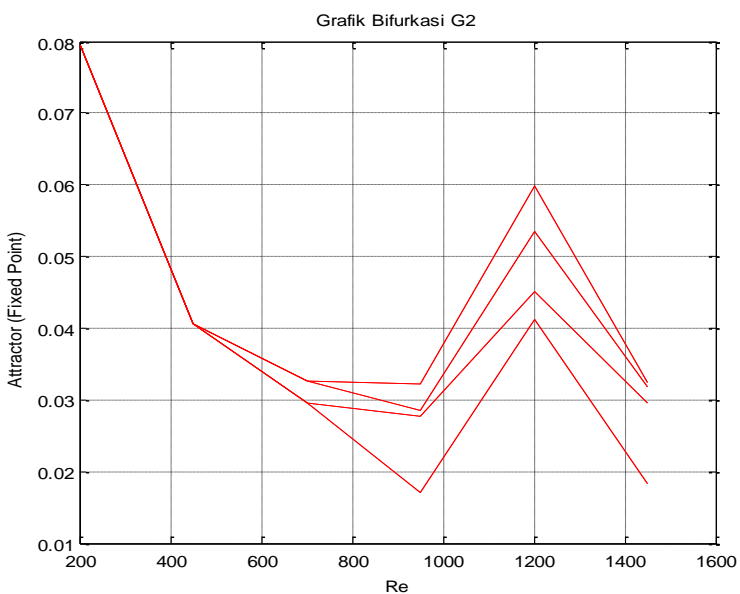

Gambar 17. Diagram bifurkasi aliran fluida pada saluran beralur dengan jarak antar alur $3 / 4 \mathrm{~K}$

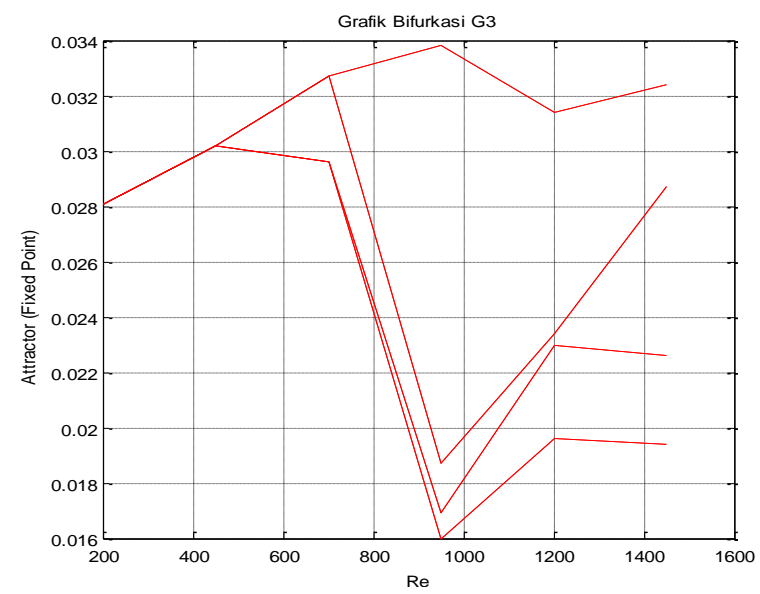

Gambar 18. Diagram bifurkasi aliran fluida pada saluran beralur dengan jarak antar alur K

\section{KESIMPULAN}

Berdasarkan hasil dan pembahasan disimpulkan hal-hal sebagai berikut:

1. Aliran fluida periodik dalam saluran yang beralur melintang mengalami chaos pada bilangan Reynold Re 950 untuk saluran tanpa alur dan bilangan Reynold Re 700 untuk saluran beralur.

2. Chaos pada aliran fluida laminar dapat dimanfaatkan untuk meningkatkan proses transport energi maupun massa.

\section{DAFTAR PUSTAKA}

[1] Moon, F. C., Chaotic and Fractal Dynamics, John Wiley \& Sons, Inc. New York, 1992.

[2] Ueda, T., Chaotic Dynamics and Its Application in Mechanical Engineering, Collaboration Workshop on Energy, Environment, and New Trend in 
Mechanical Engineering, Brawijaya University, 159-174, 2004.

[3] Tufillaro N.B. et. al., An Experimental Aproach to Non Linear Dynamics and Chaos, Addison Wesley, 1992.

[4] Adhaci, T. and Uehara, H., Linear Stability Analisys of Flow in a Periodically Grooved Channel, International Journal for Numerical Methods in Fluids (41), 601613, 2003.

[5] Nishimura, T., Morega, A.M. and Kunitsugu, K., Vortex Structure and Fluid Mixing in Pulsatile Flow Through Periodically Grooved Channels at Low Reynold Numbers, JSME International Journal Series B, Vol. 40, No. 3, 377-385, 1997.

[6] Wardana, I. N. G., Chaos in Fluid Mechanics for Energy Conservation, Collaboration Workshop on Energy, Environment, and New Trend in Mechanical Engineering, Brawijaya University, 175-192, 2004.

[7] Williams, G. P., Chaos Theory Tamed, Joseph Henry Press, Washington, D. C., 1997.
[8] Campbell, D. K., Nonlinear Science, from Paradigms to Practicalities, Los Alamos Science Special Issue, 218-262, 1987.

[9] Hassani, S., Mathematical Methods for Student of Physics And Relations Fields, Springer, Illinois, USA, 2008.

[10] White, F. M., Viscous Fluid Flow, Second edition, McGraw-Hill, Inc, 1991.

[11] Raishingania, M.D., Fluid Dynamics (With Hydrodynamics) Fourth revised edition, S. Chand \& Company LTD. New Delhi, 2002.

[12] Nishimura, T., Yoshinaka, M., and Kunitsugu, K., Oscillatory Momentum Transport and Fluid Mixing in Grooved Channels for Pulsatile Flow, Department of Mechanical Engineering, Yamaguchi University, Ube, 755-8611, Japan, 2001.

[13] Gloerfelt, X.; Bogey, Ch.; Bailly, Ch. and Juve, D., Aerodynamic Noise Induced by Laminar and Turbulent Boundary Layer Over Rectangular Cavities, American Institute of Aeronautics and Astronautics, 2476, 2002. 